\title{
SUPPRESSION OF SOIL-BORNE ROOT PATHOGENS OF ARID LEGUMES BY Sinorhizobium saheli
}

\author{
R. Gautam, S.K. Singh ${ }^{*}$ and V. Sharma ${ }^{1}$ \\ Central Arid Zone Research Institute, Jodhpur-342003, Rajasthan, India
}

\begin{abstract}
The productivity of arid legumes in arid and semi-arid tracks remains virtually stagnant over decades because of their susceptibility to root diseases. The information on interaction of beneficial nitrogen fixing rhizobia with particular reference to arid legumes of the region is limited. Systematic studies on predominant species Sinorhizobium saheli in management of root pathogens in arid legumes were undertaken. In-vitro interactions of root pathogens and $S$. saheli isolated from arid legumes significantly suppressed the growth of all fungal pathogens in presence of $S$. saheli. In addition the growth of Rhizobium was stimulated in presence of different root pathogens. A field experiment on integrated disease managementexhibited that the maximum root nodulation with the maximum seed yield of $1325 \mathrm{~kg} / \mathrm{ha}$ was observed from treatment where seeds were treated with $S$. saheli. Whereas, the minimum root nodulation was recorded in treatment, where a mixture of isolated fungal root pathogens were co-inoculated with $S$. Saheli was recorded from cowpea. The minimum seed yield was recorded from treatment wherein the mixture of isolated root pathogens of arid legumes was co-inoculated with $S$. Saheli due to increased disease pressure. The results of in-vitro and in-vivo efficacy of $S$. saheli strains suggest that their co-inoculation with PGPR's can not only reduce the use of chemical fertilizers but also can significantly enhance yields by increasing plant growth and suppressing soil borne plant pathogenic fungi.
\end{abstract}

Keywords: Clusterbean, Cowpea, Moth bean, Horse gram, Root pathogens, Management

\section{INTRODUCTION}

Clusterbean, cowpea, moth bean and horse gram are predominantly grown in arid and semi-arid tracks of Indian subcontinents under rainfed conditions (Chillar, 2009). During Kharif, high temperature coupled with moisture stress put them into abiotic and biotic stresses. The productivity of arid legumes remains virtually

\footnotetext{
* Corresponding author email: sksingh1111@hotmail.com

${ }^{1}$ Department of Biosciences and Biotechnology, Banasthali Vidhyapeeth, Banasthali-304022, Rajasthan, India
}

Received: 15.07.2014 
stagnant over decades because of their susceptibility to root diseases. Most of these root pathogens are soil and or seed-borne. The fungi belonging to the genera Rhizoctonia, Fusarium and Neocosmospora are the most destructive plant pathogens with a very wide host range causing substantial damages and yield reduction in arid legumes (Patel et al., 1998; Fawole et al., 2006; Gautam et al., 2014).

The association between rhizobia and some members of leguminosae accounts for $80 \%$ biologically fixed nitrogen and contributes $25-30 \%$ of the world wide protein intake. The ability of rhizobia to inhibit certain soil-borne plant pathogens has enlarged the importance of rhizobia besides their use in nitrogen fixation. The dual role of the species of Rhizobium in plant growth promotion and disease control is receiving increasing attention in sustainable agriculture (Mallesh, 2008). The antagonistic and plant growth promotion properties of $R$. leguminosarum b.v. phaseoli against root rot caused by $F$. solani $\mathrm{f}$.s. phaseoli in bean (Buonassisi et al., 1986), and $R$. japonicum against root rot diseases caused by $F$. solani and $M$. phaseolina in soybean have been demonstrated (Al-Ani et al., 2012).

Essalmani and Lahlou (2003) found that cultural filtrate of R. leguminosarum and heat killed bacterial cell protected lentil plants from infection by $F$. oxysporum significantly. In-vitro hyphal growth of $F$. oxysporum was suppressed by multiplication of $R$. meliloti in a mixed culture, while in soil, it reduced the severity of root rot of lucerne (Sawada, 1982).

Chakraborty andChakraborty in 1989 experimented that bacterization of seeds with $R$. leguminosarum was highly effective in reducing severity of $F$. solani root rot of pea under field condition but not much antagonistic effect was observed under invitro interaction. Sinorhizobium sp. strain NGR 234 formed nodules on 112 plant genera (Ausmeeset al., 2004). Singh et al. (2011) found that S. saheli isolate (PC- 6) from Prosopis cineraria was crossed infective to Acacia senegal.

The information on interaction of beneficial nitrogen fixing rhizobia with particular reference to arid legumes of the region is limited. Therefore, systematic studies on predominant species Sinorhizobium saheli in management of root pathogens in arid legumes were undertaken.

\section{MATERIAL AND METHODS}

Field surveys were conducted during Kharif 2012 and 2013 to collect major root pathogens and rhizobia from Jodhpur, Bikaner and Jaipur districts of Rajasthan. Molecular characterized cultures of root pathogens and putative strains of Sinorhizobium saheli were used for in-vitroand field evaluation trials (Table-1).

\section{In-vitro interaction}

Pure cultures of predominant rhizobial species Sinorhizobium saheli were raised in Petri plates containing yeast mannitol agar medium (31.82 $\mathrm{g} \mathrm{litre}^{-1}$ containing yeast extract: $1 \mathrm{~g}$, mannitol: $10 \mathrm{~g}$, di-potassium phosphate: $0.50 \mathrm{~g}$, 
magnesium sulphate: $0.20 \mathrm{~g}$, sodium chloride: $0.10 \mathrm{~g}$, Congo red: $0.025 \mathrm{~g}$ and agar: $20 \mathrm{~g}$ in one litre distilled water). Whereas, all fungal pathogenic isolates were raised in Petri plates containing PDA (39 $\mathrm{g} \mathrm{l}^{-1}$ containing potatoes infusion form: $200 \mathrm{~g}$, dextrose: $20 \mathrm{~g}$ and agar $15 \mathrm{~g}$ in one litre $\mathrm{dH}_{2} \mathrm{O}$ ). Since there are large number of natural and synthetic culture media well known for growing pure cultures of microorganism including rhizobia and fungi, several nutrient media namely PDA, malt extract agar (MEA), nutrient agar (NA), luria broth (LA), yeast mannitol agar (YEMA), rose bengal agar (RBA) and potato rose bengal agar (PRBA) were initially tested for dual cultures for simultaneous luxuriant growth of root pathogens and gram-negative strains of rhizobia for interaction studies.

Since no single tested culture medium supported the luxuriant growth of both fungal pathogens and rhizobia concurrently, a combination of PDA and YEMA in half strength (19.5 g of PDA and 15.9 g of YEMA of Hi Media Company) was used to grow dual cultures. A $5 \mathrm{~mm}$ disc of different fungal root pathogens was aseptically transferred onto one side of the Petri plate and a loop full of rhizobial culture was streaked on the other side of the Petri plate and kept for 96 hours in a BOD incubator at $25^{\circ} \mathrm{C} \pm 2{ }^{\circ} \mathrm{C}$. Fungal root pathogens or rhizobial cultures alone on one side of the Petri plate served as control. The relative growth of each microorganism was measured after 96 hours in control (in absence of other microorganism) and in presence of rhizobia for each interaction in four repeats.

\section{Integrated disease management}

\section{Field experimentation}

A field experiment was conducted in Central Research Farm of Central Arid Zone Research Institute (CAZRI), Jodhpur in randomized block design (RBD) during July, 2013 under rainfed conditions. A putative variety of each arid legume namely cowpea (PGCP- 6), moth bean (CAZRI- Moth 2), guar (RGC- 936) and horse gram (Maru) was treated with rhizobia and or pathogens and then sown in three meter rows in three repeats. The row to row and plant to plant distances were $30 \mathrm{~cm}$ and $10 \mathrm{~cm}$, respectively.

\section{Seed pelleting}

A sticky solution was prepared by dissolving $100 \mathrm{~g}$ of Jaggery and $50 \mathrm{~g}$ of Acacia senegal gum in one litre of sterile distilled water by continuous stirring and boiling the water for $15 \mathrm{~min}$. and subsequently cooling it to ambient temperatures. Five $\mathrm{ml}$ of sticky solution was mixed with $5 \mathrm{ml}$ of liquid microbial culture with 20 gm of $\mathrm{CaCO}_{3}$ and 60-80 $\mathrm{g}$ of seed per replication and allowed to dry for half an hour.

\section{Microbial inoculum}

Composite inocula of two Sinorhizobium saheli strains was prepared in $200 \mathrm{ml}$ Luria broth culture medium on rotary shaker overnight. Each fungus was multiplied on boiled and sterilized wheat grains mixed with $2 \% \mathrm{CaSO}_{4}$ and $0.5 \% \mathrm{CaCO}_{3}$ for 2 weeks. Pure culture of each fungus was then mixed with $200 \mathrm{ml}$ of sterilized distilled 
water and blended in a mixture thrice for 45 seconds. Fungal mycelium and or spores were filtered through doubled layered muslin cloth. The inocula prepared this way were used for seed pelleting as per the treatment required and pathogenicity tests.

\section{Treatments}

Each arid legume had nine seed treatments: $\mathrm{T}_{1}=$ seed treatment with Rhizobia (Sinorhizobium saheli), $\mathrm{T}_{2}=$ mixture of Macrophomina phaseolina and Rhizoctonia bataticola, $\mathrm{T}_{3}=$ mixture of Neocosmospora vasinfecta and $N$. striata, $\mathrm{T}_{4}=$ mixture of Fusarium spp. $(F$. acutatum $+F$. oxysporum $+F$. solani $), \mathrm{T}_{5}=\mathrm{T}_{1}+\mathrm{T}_{2}, \mathrm{~T}_{6}=\mathrm{T}_{1}+\mathrm{T}_{3}, \mathrm{~T}_{7}=$ $\mathrm{T}_{1}+\mathrm{T}_{4}, \mathrm{~T}_{8}=$ mixture of all fungal root pathogens and $S$. Saheli and $\mathrm{T}_{9}=$ control (without any inoculation).

\section{Observations}

The effect of seed treatments on root nodulation in different arid legumes was observed at flowering stage. Three plants were uprooted from each replication and a total of nine plants per treatment were taken into account for counting of number of root nodules. Healthy plants were watered before uprooting the plants to keep the root system intact. The uprooted plants were washed in running tap water and then total number of nodules was counted per plant. Whereas, the seed yield was recorded after harvest from each replication comprising of three four meter rows separately and average values of each replication was taken into consideration for assessing the effect of interaction of rhizobia with root rot pathogens on seed yield of arid legumes. The seed yields were converted into killogram $(\mathrm{kg})$ for assessing the effect of root nodulation on root rot pathogens of seed yield.

\section{RESULTS AND DISCUSSION}

Isolations from diseased roots of arid legumes revealed association of fungal pathogens belonging to different genera Macrophomina, Fusarium, Neocosmospora and Syncephalastrum and healthy roots yielded a predominant rhizobial species Sinorhizobium saheli and their identity validated at molecular level (Table 1). No single media tested could support simultaneous luxuriant growth of both types of microorganisms. Finally a combination of two nutrient culture media i.e., PDA (for pathogens) and YEMA (for rhizobia) in half strength supported the growth of both i.e., root pathogens and $S$. saheli equally well. A large number of plants were associated with nodules because it is inherent characteristics of leguminous plants to form nodules under natural growing conditions (Wei et al., 2002; Garcia-Fraile et al., 2007). Earlier researchers also did not find host specificity at species or genus level in different rhizobial species and their leguminous host (Ausmees et al., 2004; Singh et al., 2011).

The data regarding the relative growth of each microorganism measured after 96 hours in absence and presence of rhizobia are presented vide table 2 . The combination of PDA and YEMA supported the growth of both fungal pathogens and 
rhizobia because the most of the rhizobia are readily isolated on YEMA and fungal pathogens on PDA. In-vitro interactions of root pathogens and S. saheli isolated from arid legumes significantly suppressed the growth of all fungal pathogens tested in presence of rhizobia. Additionally, the growth of Rhizobium was stimulated in presence of different root pathogens. It is evident from the data that $S$. saheli readily grew and showed $42.5 \mathrm{~mm}$ growth in absence of root pathogens whereas different fungal root pathogens varied significantly in their rate of growth.

Out of eight fungal strain, three fungal strains namely of $M$. phaseolina, $R$. bataticola and $N$. vasinfecta completed the maximum growth of $85 \mathrm{~mm}$ by the end of 96 hrs. Whereas, other five strains namely $N$. striata, $F$. acutatum, $F$. oxysporum, $F$. solani and $S$. monosporum showed almost half of the growth which ranged from 42 to $44.5 \mathrm{~mm}$ in the stipulated time.

Inhibitory effects on growth of pathogenic fungi by in-vitro Rhizobium strains isolated from various legumes have been reported by a number of researchers. Sharif et al. (2003) used dual culture inoculation technique on potato dextrose culture medium. Kucuk (2013) studied interactions between pathogenic fungi and rhizobial strains on yeast glucose mineral agar (YGMA) culture medium by recording inhibition of radial fungal mycelium growth in presence or absence of rhizobia to determine the inhibitory effects of rhizobia against $F$. oxysporum, $F$. moniliforme, $F$. solani, and F. culmorum solid media in Petri plates by dividing them in two halves by marking with permanent marker. Rhizobium species significantly reduced wilt and root rot on common bean and chickpea caused by Fusarium species (Akhtar and Siddqui, 2007; Arfaoui et al., 2007).

The maximum root nodulation and seed yield was recorded in treatment $\mathrm{T}_{1}$ where seeds were treated with $S$. saheli. Whereas, the minimum root nodulation and seed yield was recorded in treatment $\mathrm{T}_{8}$ where a mixture of all the fungal root pathogens were co-inoculated with $S$. Saheli. Whereas, the minimum nodulations in all the arid legumes in treatment $\mathrm{T}_{8}$ wherein mixture of all the fungal pathogens were co-inoculated with $S$. saheli was due to high competition from root infecting pathogenic fungi and reduced number of nodules as compare to un-inoculated control. The number of nodules did not vary significantly in most of the treatments as compare to control except $\mathrm{T}_{1}$ because of presence of pathogenic fungi with or without S. saheli.

Several species of Rhizobium and Bradyrhizobium have been reported to restrict the growth of $M$. phaseolina. Biocontrol mechanism of rhizobia may involve the production of antibiotics, HCN, siderophores and/or phytoalexins which acts against plant pathogenic microorganism. Inhibition of microbes was most likely due to expression of essential metabolites produced in excess by the interacting 
microorganisms in a medium where it is in limited supply (Arfaoui et al., 2007). The amount and variety of nutrients available to the interacting organisms in the soil are very different to those of culture media (Kucuk, 2013).

Treatment $\mathrm{T}_{1}$ resulted in the maximum seed yield due to inoculation with mixture of $S$. saheli strains that had no competition with any root pathogenic fungi. The reduction in seed yield in other treatments as compare to control was due to attack by root rot pathogenic fungi. The treatment $T_{4}$ followed by treatment $T_{2}$ wherein mixture of Fusarium spp.and M. phaseolina $+R$. bataticola were coinoculated as seed treatments resulted in the minimum seed yields because of absence of growth promoting $S$. saheli strains. Co-inoculations of $S$. saheli with one of the major pathogenic fungi i.e. treatment $\mathrm{T}_{5}(S$. saheli $+M$. phaseolina $), \mathrm{T}_{6}(S$. sahel + Neocosmospora spp.) and $\mathrm{T}_{7}(S$. saheli + Fusarium spp.) resulted in better yields than in treatments $T_{2}, T_{3}$ and $T_{4}$ where seeds were treated with only one major pathogenic fungus. This clearly indicates the inhibitory effect of $S$. saheli on different pathogenic fungi in all the four arid legumes tested.

Species of Rhizobium have been shown to reduce root rotsand wilts in legumescaused by M. phaseolina, R. solani and Fusarium spp. (Haque and Ghaffar, 1993, Akhtar and Siddqui, 2007; Arfaoui et al., 2007).Khalequazzaman and Hossain (2008) suggested that seed treatment with Rhizobium strain BINAR P36 not only control foot and root rot but also increased green pod yield in $P$. vulgaris.

Hossain et al. (2000) observed reduction in fusarial foot and root rot in chickpea over untreated control with Rhizobium inoculation@ @ $50 \mathrm{~g} \mathrm{~kg}^{-1}$ seed. Treatments of seeds with bio-fertilizer substantially reduced death of plant in lentil and chickpea due to infection by S. rolfsii. Kumar et al. (2006) assessed the genetic diversity of PGPR isolated from Macuna pruriens. Among the five isolates, only MPR4 inhibited the growth of $M$. phaseolina and $F$. oxysporum. They observed that fungal inhibition was more pronounced in dual culture conditions in comparison to that of cell free culture filtrate. Huang and Erickson (2007) proved that seed treatment with $R$. leguminosarum b.v. viceae was effective in controlling damping off in pea under naturally infested field condition.

Mazen et al. (2008) evaluated the antagonistic activities of the cultural filtrates of $R$. leguminosarum and arbuscular mycorrhiza (AM) fungi in the management of damping off and root rot diseases of faba bean. They observed that soaking of faba bean seeds in cultural filtrate of Rhizobium species individually or in combination with AM fungi not only act as bio-protection agents against root rot diseases but also substantially increase plant growth and yield.

Effect of seed treatment on root nodulation in arid legumes is presented in figure 1. Nine seed treatments resulted in significant variations in number of root nodules and seed yield. The data clearly exhibited that the maximum root nodulation as observed in treatment $\mathrm{T}_{1}$ where seeds were treated with $S$. saheli strain CP-R4. 
Whereas, the minimum root nodulation was recorded in treatment $T_{8}$ where a mixture of all the fungal root pathogens were co-inoculated with S. Saheli. Nevertheless, statistically most of the treatments except $\mathrm{T}_{1}$ were at par with that of control.

Effect of seed treatment on seed yield in arid legumes is shown in figure 2 . The maximum seed yield of $1325 \mathrm{~kg} \mathrm{ha}^{-1}$ was recorded from cowpea and the minimum seed yield of $483 \mathrm{~kg} \mathrm{ha}^{-1}$ was recorded from horse gram. The treatment $\mathrm{T}_{1}$ resulted the maximum seed yield which was significantly higher compared to all other treatments. The minimum seed yield was recorded from treatment $\mathrm{T}_{8}$ where the mixture of all the root pathogens of arid legumes was co-inoculated with S. saheli due to increased disease pressure.

Significantly higher number of nodules was recorded from treatment $\mathrm{T}_{1}$ where mixture $S$. saheli strains were used for seed coatings was because $S$. saheli has a wide host range and therefore could infect all the four arid legumes tested (Rasanen et al., 2001; Singh et al., 2011). Sinorhizobium species strain NGR 234 formed nodules on more than 100 plant genera (Ausmees et al., 2004). Singh et al. (2011) found that $S$. saheli isolate (PC-6) from Prosopis cineraria was cross infective to Acacia senegal. Chickpea rhizobia were both phenotypically and genotypically diverse and were closer to Mesorhizobium or Sinorhizobium species and distinct from Bradyrhizobium (Maatallah et al., 2002). R. leguminosarum biovars confer host specificity on nodulation such as biovar viciae on peas, biovar phaseoli on beans etc. Whereas, symbiotic genes are carried on plasmids which are interchanged (Young et al., 2006).

Seed dressing or soil drenching with $R$. leguminosarum reduced the infection of $M$. phaseolina, $R$. solani and Fusarium spp. in both leguminous and nonleguminous plants under field conditions (Haque and Ghaffar, 1993). Huang and Erickson (2007) observed significantly reduced incidence of damping-off, promoted seedling growth and increased root nodule mass, plant biomass and seed yield of pea and lentil due to Elkoca et al. (2008) observed that seed inoculation of chickpea with Rhizobium significantly increased the seed yield under different inoculation treatments which ranged between by $18.0 \%$ to $30.5 \%$ over the control.

\section{CONCLUSION}

Drawbacks of intensive farming practices and environmental costs of nitrogen (N) and phosphorus fertilizers have renewed interest in biofertilizers. The results of in-vitro and in-vivo efficacy of $S$. saheli strains suggest that their co-inoculation with PGPR's can not only reduce the use of chemical fertilizers but also can significantly enhance yields by increasing plant growth and suppressing soil borne plant pathogenic fungi. 
R. Gupta et al.

\section{ACKNOWLEDGEMENTS}

First author is grateful to the University Grants Commission for providing financial assistance in the form of fellowship to carry out this study.

\section{REFERENCES}

Akhtar, M.S., and Siddqui, Z.A. 2007. Effects of Glomus fasciculatum and Rhizobium spp. on the growth and root rot disease complex chickpea. Archieves of Phytopathology and Plant Protection, 40:37-43

Al-Ani, R.A., Adhab, M.A., Mahdi, M.H., and Abood, H.M. 2012. Rhizobium japonicum as a biocontrol agent of soybean root rot disease caused by Fusarium solani and Macrophomina phaseolina. Plant Protection Science, 48 (4):149-155

Arfaoui, A., El Hadrami, A., Mabrouk, Y., Sifi, B., Boudabous, A., El Hadrami, I., Daayf, F. and Cherif, M. 2007. Treatment of chickpea with Rhizobium isolates enhances the expression of phenylpropanoid defense related genes in response to infection by Fusarium oxysporum f.sp. ciceris. Plant Physiology and Biochemistry, 45:470-479

Ausmees, N., Kobayashi, H., Deakin, W.J., Marie, C., Krishnan, H.B., Broughton, W.J., and Perret, X. 2004. Characterization of NopP, a type III secreted effector of Rhizobium sp. strain NGR234. Journal of Bacteriology, 18:4774-4780

Buonassisi, A.J., Copeman, R.J., Pepin, H.S., and Eaton, G.W. 1986. Effect of Rhizobia spp. on Fusarium f.sp. phaseoli. Canadian Journal of Plant Pathology, 8:140-146

Chakraborty, U., and Chakraborty, B.N. 1989. Interaction of Rhizobium leguminosarum and Fusarium solani f.sp. pisi on pea affecting disease development and phytoalexin production. Canadian Journal of Botany, 67:1698-1701

Chhillar, B.S. 2009. Management of insect pests and diseases of pulses with special reference to arid legumes. In Legumes in Dry Areas (eds. D. Kumar, A. Henry and K.P.R. Vittal). Indian Arid Legume Society, Scientific Publishers, Jodhpur, India, PP- 447-449

Elkoca, E., Kantar, F., and Sahin, F. 2008. Influence of nitrogen fixing and phosphorus solubilizing bacteria on the nodulation, plant growth, and yield of chickpea. Journal of Plant Nutrition, 31(1):157-171

Essalmani, H., and Lahlou, H. 2003. Mécanismes de bioprotection des plantes de lentille par Rhizobium leguminosarum contre Fusarium oxysporum f. sp. Lentis. Biologies, 326:1163-1173

Fawole, O.B., Ahmed, O., and Balogum, O.S. 2006. Pathogenicity and cell wall degrading enzymes activities of some fungal isolates from cowpea [Vigna unguiculata (L.) Walp]. Biokemistri, 18(10):45-51

Garcia-Fraile, P., Rivas, R., Willems, A., Peix, A., Martens, M., Martinez-Molina, M., Mateos, P.F., and Velazquez, E. 2007. Rhizobium cellulosilyticum sp. nov., isolated from sawdust of Populas alba. International Journal of Systematic and Evolutionary Microbiology, 57:844-848

Gautam, R., Singh, S.K., and Sharma, V. 2014. RAPD and nuclear rDNA ITS polymorphism within Macrophomina phaseolina isolated from arid legumes of western Rajasthan. 
Proceedings of the National Academy of Sciences, India Section B: Biological Sciences, 84 (1):171-181

Haque, S.E., and Ghaffar. A. 1993. Use of Rhizobia in the control of root rot disease of sunflower, okra, soybean and mungbean. Journal of Phytopathology, 138 (2):157-163

Hossain, I., Jalil, M. A., Khan, M. A. I., and Aminuzzaman, F. M. 2000. Seed treatment with Rhizobium and N P K nutrition on disease incidence and yield of chickpea (Cicer arietinum L.). Bangladesh Journal of Seed Science and Technology, 4:1-6

Huang, H.C. and Erickson, R.S. 2007. Effect of seed treatment with Rhizobium leguminosarum on Pythium damping-off, seedling, height, root nodulation, root biomass, shoot biomass and seed yield of pea and lentil. Journal of Phytopathology, $155: 31-37$

Khalequzzaman, K.M., and Hossain, I. 2008. Efficacy of Rhizobium strains and biofertilizers for controlling foot and root rot and increasing green pod yield of bush bean. Bangladesh Journal of Agricultural Research, 33 (3):617-622

Kucuk, C. 2013. In-vitro antagonism of Rhizobium strains isolated from various legumes. Journal of Applied Biological Sciences, 7(1):24-30

Kumar, B., Kumar, M.S., Annapurna, K., and Maheshwari, D.K. 2006. Genetic diversity of plant growth promoting rhizobia isolated from a medicinal legume, Mucuna pruriens Linn. Current Science, 91 (11):1524-1529

Maatallah, J., Berraho, E. B., Muñoz, S., Sanjuan, J., andLluch, C.2002. Phenotypic and molecular characterization of chickpea rhizobia isolated from different areas of Morocco. Journal of Applied Microbiology, 93:531-540

Mallesh, S.B. 2008. Plant growth promoting rhizobacteria, their characterization and mechanisms in the suppression of soil borne pathogens of coleus and ashwagandha. Ph. D thesis, Department of Plant Pathology, College of Agriculture, Dharwad, University of Agricultural Sciences, Dharwad - 580 005, India, P- 160

Mazen, M.M, El-Batanony, N.H., El-Monium, M.M.A., and Massoud, O.N. 2008. Cultural filtrate of Rhizobium spp. and arbuscular mycorrhiza are potential biological control agents against root rot fungal diseases of faba bean. Global Journal of Biotechnology and Biochemistry, 3 (1):32-41

Patel, D.S., Patel, S.I., Desai, B.G., and Khandar, R.R. 1998. Neocosmospora vasinfecta an incitant of wilt of clusterbean. Indian Phytopathology, 51 (3):305

Rasanen, L.A., Sprent, J.I., and Lindstrom, K. 2001. Symbiotic properties of Sinorhizobia isolated from Acacia and Prosopis nodules in Sudan and Senegal. Plant and Soil, 235:193-210

Singh, S.K., Pancholy, A., Jindal, S.K. and Pathak, R. 2011. Effect of plant growth promoting rhizobia on seed germination and seedling traits in Acacia Senegal. Annals of Forest Research, 54(2):1-9

Wei, G.H., Wang, E.T., Tan, Z.Y., Zhu, M.E. and Chen, W.X. 2002. Rhizobium indigoferae sp. nov. and Sinorhizobium kummerowiae sp. nov., respectively isolated from Indigofera spp. and Kummerowia stipulaceae. International Journal of Systematic and Evolutionary Microbiology, 52:2231-2239 
Yao, Z.Y., Kan, F.L., Wang, E.T., Wei, G.H., \& Chen, W.X. 2002. Characterization of rhizobia that nodulate legume species of the genus Lespedeza and description of Bradyrhizobium yuanmingense sp. nov. International Journal of Systematic and Evolutionary Microbiology, 52:2219-2230

Young, J.P.W., Crossman, L.C., Johnston, A.W.B., Thomson, N.R., Ghazoui, Z.F., Hull, et al. 2006. The genome of Rhizobium leguminosarum has recognizable core and accessory components. Genome Biology, 7:R34

Yao, Z.Y., Kan, F.L., Wang, E.T., Wei, G.H., \& Chen, W.X. 2002. Characterization of rhizobia that nodulate legume species of the genus Lespedeza and description of Bradyrhizobium yuanmingense sp. nov. International Journal of Systematic and Evolutionary Microbiology, 52:2219-2230

Young, J.P.W., Crossman, L.C., Johnston, A.W.B., Thomson, N.R., Ghazoui, Z.F., Hull, et al. 2006. The genome of Rhizobium leguminosarum has recognizable core and accessory components. Genome Biology, 7:R34 
Table 1. Molecular Identification of fungal root pathogens and rhizobial strains of arid legumes

\begin{tabular}{l|l|l|l}
\hline Origin & Isolate & Molecular Identification & Gen Bank accession number \\
\hline Jodhpur & JD-HG1 & Macrophomina phaseolina & JQ954868 \\
Jodhpur & JD-CP5 & Rhizoctonia bataticola & JQ954872 \\
Jodhpur & JD-HG10 & Neocosmospora vasinfecta & JQ954881 \\
Jaipur & JAI-CP11 & Neocosmospora striata & JQ954882 \\
Jaipur & JAI-CP16 & Fusarium acutatum & JQ954883 \\
Bikaner & BK-CB15 & $\begin{array}{l}\text { Syncephalastrum } \\
\text { monosporum }\end{array}$ & JQ954886 \\
& & Fusarium solani & JQ954888 \\
Bikaner & BK-CB20 & Fusarium sp. & JQ954890 \\
Jaipur & JAI-CB37 & Fusarium oxysporum & JQ954892 \\
Jaipur & JAI-MB24 & Fus & KC794787 \\
Jodhpur & HG-R4 & Sinorhizobium saheli & KC794788 \\
Jodhpur & HG-R6 & Sinorhizobium saheli & K
\end{tabular}

Table 2. In-vitro interactions of root pathogens and Rhizobium (S. saheli) isolated from arid legumes

\begin{tabular}{l|l|l|l|l}
\hline \multirow{2}{*}{ Isolate } & \multirow{2}{*}{ Pathogen } & \multicolumn{3}{|c}{ Growth (mm) } \\
\cline { 3 - 5 } & & $\begin{array}{l}\text { Fungus } \\
\text { alone }\end{array}$ & $\begin{array}{l}\text { Fungus }+ \\
\text { Rhizobium }\end{array}$ & $\begin{array}{l}\text { Rhizobium } \\
\text { alone }\end{array}$ \\
\hline JD-HG5 & M. phaseolina & 85 & $40+45$ & 42.5 \\
BK-MB8 & R. bataticola & 85 & $42+43$ & 42.5 \\
BK-CB17 & N. vasinfecta & 85 & $39+46$ & 42.5 \\
JAI-CP11 & N. striata & 42 & $38+46$ & 42.5 \\
JAI-CP16 & F. acutatum & 44.5 & $36+47$ & 42.5 \\
JAI-MB24 & F. oxysporum & 43.5 & $38+43$ & 42.5 \\
JAI-MB21 & F. solani & 42 & $35+48$ & 42.5 \\
BK-CB15 & S. monosporum & 44 & $41+44$ & 42.5 \\
CD at 0.05\% & & 3.3 & $1.2 ; 2.1$ & 0.8 \\
\hline
\end{tabular}




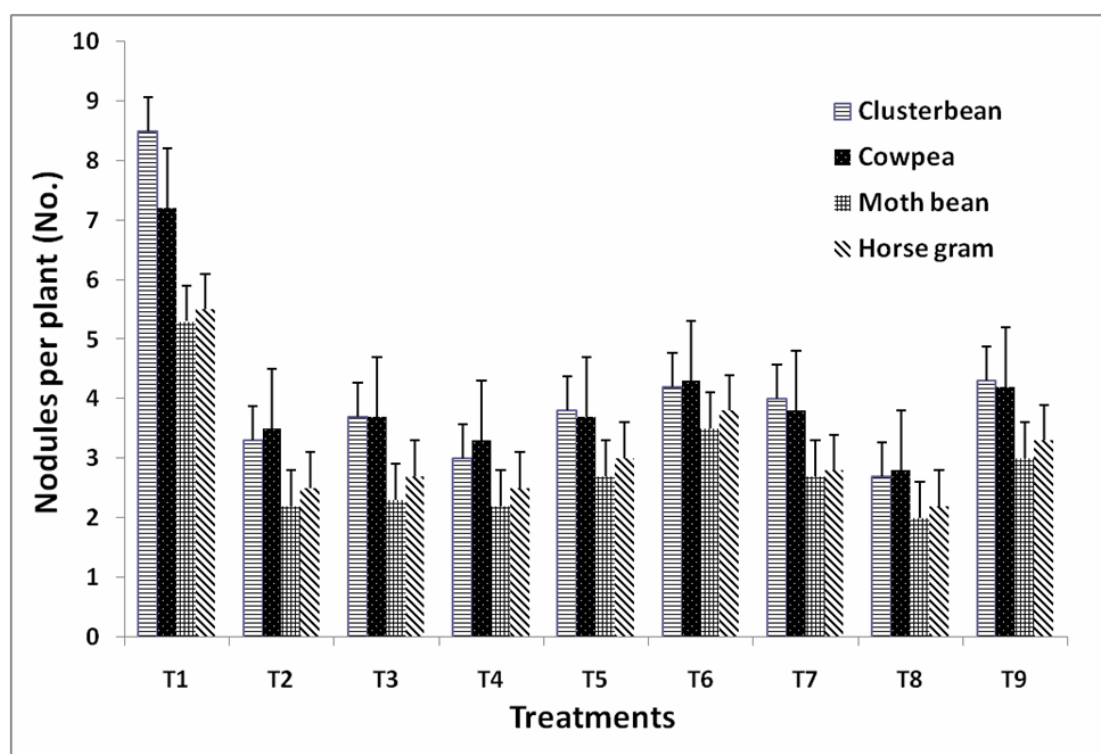

Figure 1. Effect of seed treatment on root nodulation in arid legumes

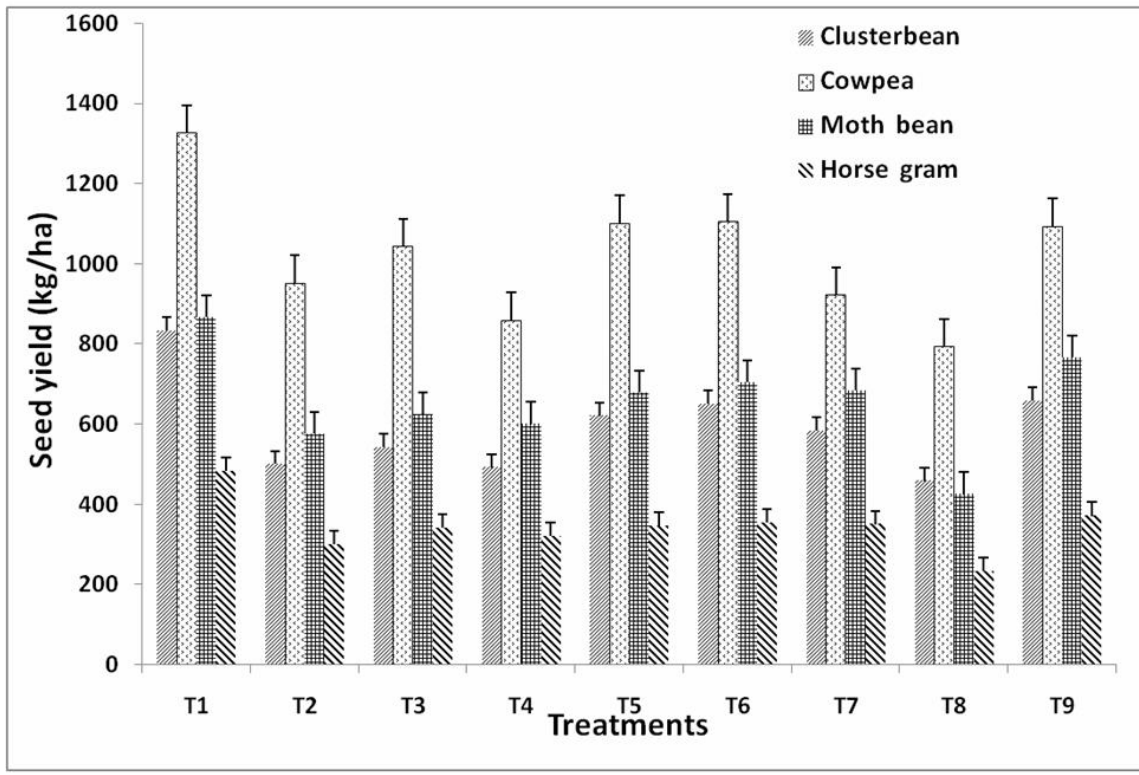

Figure 2. Effect of seed treatment in seed yield in arid legumes 